\title{
Empty in summer, crowded during migration? Structure of assemblage, distribution pattern and habitat use by bats (Chiroptera: Vespertilionidae) in a narrow, marine peninsula
}

\author{
Mateusz Ciechanowski $^{1} \cdot$ Anna Jakusz-Gostomska $^{1} \cdot$ Michal Żmihorski $^{2}$
}

Received: 26 January 2015 / Accepted: 28 September 2015 / Published online: 10 October 2015

(C) The Author(s) 2015. This article is published with open access at Springerlink.com

\begin{abstract}
According to scarce available data, the use of coastal habitats by bats appears to be the most intensive during spring and autumn migrations, when coasts become migratory corridors. Migrating bats might seasonally enrich the fauna of sea islands and peninsulas, which often are poor in bats outside the migratory season. Hel Peninsula is part of the Polish Baltic Coast that extends the most into the sea; thus, it gives unique opportunity to assess that phenomenon quantitatively. To test for seasonal variation in structure of bat assemblage and bat activity, we recorded echolocation calls on walking transects. Seven species were recorded in total, with predominance of sedentary Eptesicus serotinus in June-July and migratory Pipistrellus nathusii in August-September. Occurrence of bats was the highest in deciduous and coniferous forests and the lowest in coasts and ports. Interaction of day of year and distance to mainland was highly significant, indicating that occurrence of bats was increasing from spring to autumn but this increase depended on location. Far from mainland, the mean occurrence of bats was rather stable over time. On transects located close to the mainland, bat occurrence was low at the beginning of the season but after midAugust increased rapidly. We confirmed that some topographically isolated parts of the sea coasts can host only very impoverished summer bat fauna. Bat activity in such sites increase in autumn; however, Hel Peninsula presumably does
\end{abstract}

Communicated by: Justin G. Boyles

Mateusz Ciechanowski

matciech@kki.net.pl

1 Department of Vertebrate Ecology and Zoology, Faculty of Biology, University of Gdańsk, ul. Wita Stwosza 59, 80-308 Gdańsk, Poland

2 Department of Ecology, Swedish University of Agricultural Sciences, 75007 Uppsala, Sweden not act as a migratory corridor, but only as a target of local dispersal from mainland.

Keywords Fauna $\cdot$ Poland $\cdot$ Baltic $\cdot$ Coast $\cdot$ Distribution

\section{Introduction}

During seasonal migrations between summer and winter areas, some temperate-zone bats can travel large distances, sometimes exceeding $1900 \mathrm{~km}$ (Fleming and Eby 2004). Even large, open water bodies are not a permanent barrier for some migrating or dispersing bats (Baagøe 2001). Longdistance migrations of bats result in records of single individuals far outside a species' geographical range or even in the open sea. Species such as Nathusius' pipistrelle, Pipistrellus nathusii, the noctule, Nyctalus noctula, the serotine, Eptesicus serotinus, the parti-coloured bat, Vespertilio murinus and the northern bat, Eptesicus nilssonii are found regularly on oil platforms and ships in the North Sea (Boshamer and Bekker 2008). Bats can cross the open sea not only accidentally but also during regular migrations; it is known that migratory species ( $P$. nathusii, V. murinus, N. noctula) leave Scandinavia in autumn and fly over the Baltic Sea from the southernmost points of Sweden (Ahlén 1997). Flight over the Baltic Sea from Sweden to Poland (180-200 km) requires the use of $8 \%$ fat reserves of the bat and represents a fairly considerable achievement (Hedenström 2009). P. nathusii flying at a speed of about $20 \mathrm{~km} / \mathrm{h}$ can theoretically reach the Polish coast in about 9 h (Ahlén 1997). Eastern red bats Lasiurus borealis of North America are known to regularly migrate over the Atlantic Ocean up to $44 \mathrm{~km}$ from the shore, but there are anecdotal sightings of various bat species up to $773 \mathrm{~km}$ from the shore (Hatch et al. 2013). 
Data concerning the use of marine coastal habitats, as well as bat activity on coasts and the sea itself are scarce, even though these habitats may play crucial function in longdistance bat migrations. Along coasts in Great Britain, sandy and gravel beaches, dunes and coastal marshes are preferred by bats (Walsh and Harris 1996). In Finland, Baltic ports are used as foraging sites, especially by Daubenton's bat, Myotis daubentonii, and the northern bat, E. nilssonii (Wermundsen and Sivonen 2008). The use of coastal habitats by bats is the most intensive during the spring and autumn migrations, when the narrow strips of coast, such as sand spits between sea and lagoons become migratory corridors (Jarzembowski 2003) and extending peninsulas act as starting points or stopovers between large bodies of water (Dzal et al. 2009; McGuire et al. 2012).

Migrating bats seasonally enrich the fauna of sea islands and extending peninsulas, which are often poor in bat species and individuals outside the migratory season; for example, P. nathusii, regularly visits the Danish island of Bornholm (Baltic Sea) in autumn (Baagøe 2001). Bats even visit islands that are completely devoid of local bats, such as when the hoary bat, Lasiurus cinereus, visits small, treeless islands near the coast of California (Cryan and Brown 2007). There are also records of individual bats on islands far from their migratory pathways, probably as a result of strong winds pushing them off course (Petersen et al. 2014). Some of these examples, however, might be the result of passive transport by humans, especially via ship cargoes (Constantine 2003; Petersen et al. 2014).

In Scandinavia, bats inhabit some islands that are located far from the coast (Ahlén 1983). Factors that restrict this phenomenon include the small surface of the island, a scarcity of trees, a lack of roosts, and a low diversity and abundance of insect prey. On the smallest islands, no maternity colonies persist (due to the high energy requirements of lactating females) and only adult males settle there (Johansson and De Jong 1996). Both small marine islands and narrow, extending peninsulas can be treated as examples of landscape patches with limited possibilities of access and dispersal for bats, surrounded by large areas of unsuitable habitats, although the level of isolation in the case of islands is much higher.

The Hel Peninsula is part of the Polish Baltic Coast that extends $34 \mathrm{~km}$ into the sea. Data concerning species composition and distribution of bats that inhabit this area are lacking. There is one report of $P$. nathusii being found on a fishing boat between Hel and Gdańsk on 18 May 1928 (Lüttschwager 1939) and a breeding colony of the same species in the attic of a house in Kuźnica (Ciechanowski et al. 2000). The relative isolation of the Peninsula, its narrowness and scarcity of freshwater bodies makes it a perfect area to test whether such extended parts of sea coasts can sustain permanent bat populations or act as a temporary stopover (or even as a corridor) during seasonal migrations. Thus, the aim of this study was to examine the species composition, distribution pattern, and habitat use by bats in the narrow, coastal peninsula during the two phenological periods: breeding and the autumn migration. We hypothesized the Hel Peninsula not only hosts resident, breeding bat populations in early summer but also serves as a migratory corridor and stopover during autumn migration, leading to the following predictions: (1) spatial concentrations of foraging individuals would occur in June-July, (2) bat activity would increase between June-July and AugustSeptember periods, (3) no significant relationship would occur between distance from the mainland and bat activity both in early summer and late summer/autumn. The third prediction is based on assumption that bats from local breeding colonies commute in all directions but do not enter the Peninsula from the outside, while seasonal migrants, if using the Peninsula as a corridor, move along its whole length, from the base to the tip. Additionally, we aimed to determine if the presence of bats on the Peninsula is enhanced by winds of particular direction (e.g. associated with influx of individuals from external, mainland areas) and if the bats select habitats providing them more shelter from strong, gusty winds, typical for exposed elements of marine coast.

\section{Study area}

The Hel Peninsula is a sandbar located in northern Poland; it separates Gdańsk Bay and its internal part, Puck Bay, from the open Baltic Sea and extends along a NW-SE axis. It is $34 \mathrm{~km}$ long and its width ranges from $150 \mathrm{~m}$ near Kuźnica village to $3000 \mathrm{~m}$ in Hel city. The total land surface of the Peninsula is $31.3 \mathrm{~km}^{2}$. Its area is mostly covered by sand dunes (reaching $23 \mathrm{~m}$ a.s.1., Przewoźniak 1979), the highest of which are found in the narrowest, northwestern part, whereas the lowest are near the wide tip (Gerstmannowa 1995). Reservoirs of fresh water are scarce and are restricted to small forest pools, swamps and marshes near Jastarnia, Chałupy and Hel.

The Hel Peninsula is under the influence of a marine climate. The mean January temperature is between 0 and $-1{ }^{\circ} \mathrm{C}$, whereas the mean July temperature is between 17 and $18{ }^{\circ} \mathrm{C}$ (Kondracki 1998). The local climate is shaped by the impact of mostly westerly winds, which reach the lowest speeds in June (Miętus et al. 2005). Characteristic features of this climate are a large number of cloudy days, a relatively high annual precipitation $(650 \mathrm{~mm})$, and a late and relatively cool summer.

Vegetation on the Peninsula demonstrates a clear zonation, typical for sand bars (Gerstmannowa 1995), with several ecosystem zones (Przewoźniak 1979): (1) beach; (2) treeless dunes with initial vegetation (along the open sea shore); (3) dunes parallel and perpendicular to the shore, covered by pine forests; (4) poorly developed dunes along the shore of Puck Bay, covered by psammophilous swards; (5) flats along the shore of Puck Bay, covered by poor meadows and reed beds; 
and (6) heath on shallow peat and muck (Machnikowski 1998). Forests (mostly either Scotch pine or birch-oak stands with small patches of swamp birch and alder woodlands) form an uninterrupted belt along the whole Peninsula, covering 1417 ha in total. The mean age of the treestands is 116 years, but on old military training grounds, they can reach 140 years (Machnikowski 1998). However, even the oldest trees are small due to the difficult conditions on the sandy dunes and strong winds - this results in a low number of hollow trees that could serve as potential roosts for bats.

Few settlements (with a collective total of about 8000 people) are present in the study area: the cities of Hel and Jastarnia, former villages that belong to Jastarnia (Kuźnica and Jurata) and the village of Chałupy. Settlements consist of mainly low houses and only a few older churches. In some parts of the Peninsula, fortifications (concrete shelters) were built just before or during World War II and have remained until recent times; additionally, the area was used as a main Polish Navy base before and after the war, resulting in several multi-storied buildings (Kondracki 1998).

\section{Materials and methods}

\section{Field studies}

The majority of data about bat fauna of the Hel Peninsula were collected by recording echolocation calls along linear transects (Jüdes 1989). We conducted the study from mid-June to the beginning of October during two seasons: 2007 and 2008. Each study season was divided into two phenological periods: (1) late pregnancy, parturition, lactation and weaning of young bats (from mid-June to the beginning of August) and (2) dispersion of nursery colonies, autumn migration and mating (August-September; Rydell et al. 2014). We did not sample the period of spring migration, as it appears to be much shorter on the Polish Baltic Sea Coast (Jarzembowski 2003 but contrary to the data from the other countries around the Baltic Sea-Rydell et al. 2014); thus, it would be hard to finish recordings on all transects before the end of the phenological period.

The 18 transects (closed polygonal chains) were established as evenly as possible along the whole Peninsula using 1:10,000 topographic maps (Fig. 1). The total length of all transects was $41.9 \mathrm{~km}$ and the mean length of the transects was $2.33 \mathrm{~km}$. With five exceptions, we visited each transect twice in both seasons, resulting in 36 recording sessions (visits) per season. Each transect was walked on foot twice during the evening, exclusively when no rain was present or a wind velocity faster than $6 \mathrm{~m} / \mathrm{s}$ was noted. The first walk began $30 \mathrm{~min}$ after sunset and lasted $45 \mathrm{~min}$ and the second walk started immediately following the first one (hereafter known as "evening" and "night" walks, respectively). The

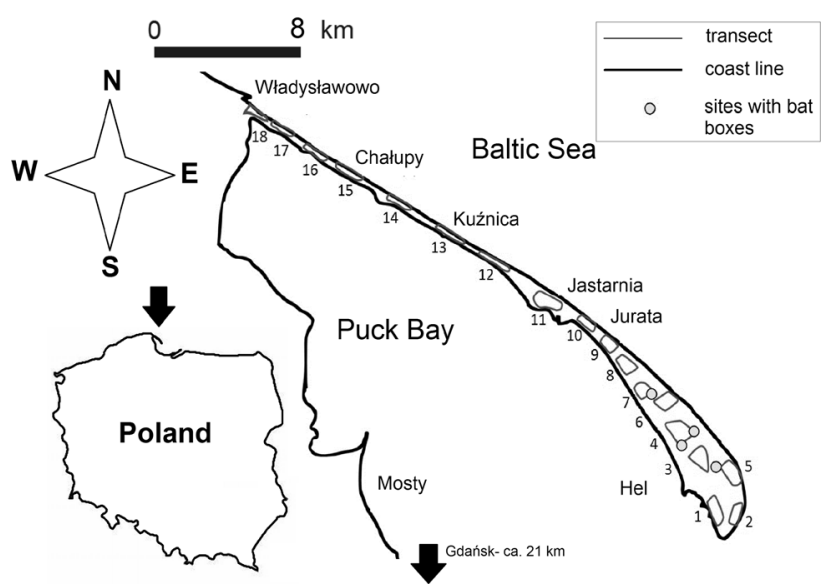

Fig. 1 Distribution of transects used for recording bat calls on the Hel Peninsula, northern Poland in years 2007-2008

two walks allowed to record the activity of species that emerge from roosts just after the sunset (Nyctalus, Eptesicus, Pipistrellus) and about $1 \mathrm{~h}$ later (some Myotis) (Jones and Rydell 1994). The transects crossed several different habitats; thus, they were divided into sections that were measured on 1:10,000 maps. The sections were classified into eight habitat classes: (1) coastal marshes (including reed beds); (2) beaches forming an uninterrupted belt along the coast of open Baltic Sea, but occurring at sites unoccupied by ports and reedbeds along the coast of Puck Bay; (3) mixed forests with a significant proportion of birch, alder and oak, besides dominating Scotch pine; (4) coniferous forests - pure stands of Scotch pine; (5) forest edge - a border between the tree stand and a built-up area, beach or any other open habitat (only if a transect crossed parallel to the edge); (6) roads and rails - an asphalt road or a railroad along the whole Peninsula, usually crossing the forest (if the road or rail ran along the forest edge, it was classified as habitat 5 , if it crossed the built-up area-as habitat 8); (7) ports-sections of transects running along wharfs and piers; and (8) built-up areas (settlements).

In 2007, we recorded bats using two narrowband ultrasound detectors (Pettersson D-100), working in heterodyne mode. One of the detectors was constantly tuned to $45 \mathrm{kHz}$ and the other to $25 \mathrm{kHz}$ to maximize the chance of detection of bat species emitting low- (Nyctalus, Eptesicus, Vespertilio) and high- (Pipistrellus, Myotis) frequency calls. If any flying bat appeared, we tuned the detectors to the frequency at which the output calls were the loudest, i.e. peak frequency (frequency of maximum amplitude). Bats were identified in the field based on how the calls sounded (tonal quality), the peak frequency, repetition rate (Table 1), visually observed silhouette and flight style (Ahlén 1990). Each of the three persons that conducted bat observations was subjected to minimum halfyear training in auditory determination of bat calls heard through a heterodyne detector, based on recordings available on CD-ROM by Barataud (1996). Additionally, a bat fauna consisted of only 11 species (Myotis nattereri, M. daubentonii, 
V. murinus, E. nilssonii, E. serotinus, Pipistrellus pipistrellus, Pipistrellus pygmaeus, P. nathusii, N. noctula, Nyctalus leisleri, Plecotus auritus) is known from the mainland areas directly adjacent to the base of the Peninsula (Ciechanowski et al. 2000; Ciechanowski 2003; Ciechanowski and Szkudlarek 2003; M. Ciechanowski, unpubl.), significantly limiting the number of taxa predicted to be present in the study area. In 2008, we recorded bats by broadband ultrasound detector (Pettersson D-230), working in a retained amplitude frequency division mode and connected to a digital audio recorder M-Audio Microtrack II. Divided-by-ten echolocation calls were recorded on a CF card and were analysed using Batsound 3.31 software (Pettersson Elektronik AB, Sweden). We determined bats to the species level, based on the general type of call (fm-QCF, FM-qcf, FM) and on the frequency of the maximum amplitude (peak frequency) and length of the interval between calls (Table 1). In both seasons, we defined a single observation as a 'pass' - a sequence of echolocation calls separated by at least a 2-min gap between the previous and the following sequence.

Weather data used for statistical analysis were provided by the weather station of the Institute of Meteorology and Water Management in Hel city (for each day when recording on any transect was conducted). The air temperature was measured $2 \mathrm{~m}$ above the ground, and wind speed and direction were monitored $23 \mathrm{~m}$ above the ground.
We checked potential summer and winter bat roosts, involving 24 bird and bat boxes (the only present in the area) near Hel city (at the beginning of August in 2007 and 2008) and 10 concrete fortifications (shelters and artillery batteries) in February 2003 and 2009. We also collected incidental data involving bats of the Hel Peninsula: individuals captured by ornithologists in mist nets on a spring bird ringing station in Kuźnica in 2007 ( $n=4)$, bats which were found grounded by local inhabitants in spring 2006 and $2013(n=2)$, and two nursery roosts in houses reported by citizens of Kuźnica (1996-1997) and Chałupy (2009) and subsequently checked by either daily visits or evening emergence counting and mist netting $(n=2)$. Some fortifications were checked again in November 2014, and 27 new styrofoam-concrete boxes (set up in autumn 2013) were inspected in August 2014.

\section{Statistical analysis}

To test for differences in the numbers of bat observations between the two phenological periods (June-August and August-October), we used the Mann-Whitney $U$ test. The Spearman rank correlation was applied to test the relationship between bat activity and the distance of a particular transect's centroid from the mainland (i.e. the base of the Peninsula). We applied the chi-squared Pearson test to check whether bat presence correlated with a particular wind direction. For this

Table 1 Diagnostic features, used for species determination of bat calls during study. A compilation based on Ahlén (1990) and Barataud (1996)

\begin{tabular}{|c|c|c|c|c|c|c|}
\hline \multirow[t]{2}{*}{ Species } & \multicolumn{3}{|l|}{ Heterodyne (2007) } & \multicolumn{2}{|c|}{ Frequency division (2008) } & \multirow{2}{*}{$\begin{array}{l}\text { Peak frequency } \\
\text { [in } \mathrm{kHz}]\end{array}$} \\
\hline & $\begin{array}{l}\text { Tonal quality at } \\
\text { peak frequency }\end{array}$ & Repetition rate & Rhythm & Call structure & Other features & \\
\hline Myotis sp. & Hard clicks & Fast & Regular & FM & - & $38-55$ \\
\hline $\begin{array}{l}\text { Vespertilio } \\
\text { murinus }\end{array}$ & Clapping & Slow & Regular & FM-QCF & $\begin{array}{l}\text { Explosive start } \\
\text { (on oscillogram) }\end{array}$ & $24-26$ \\
\hline $\begin{array}{l}\text { Eptesicus } \\
\text { nilssonii }\end{array}$ & Clapping & Slow & Irregular & FM-qcf & $\begin{array}{l}\text { Explosive start } \\
\quad \text { (on oscillogram) }\end{array}$ & $29-31$ \\
\hline $\begin{array}{l}\text { Eptesicus } \\
\quad \text { serotinus }\end{array}$ & Clapping & Slow & Irregular & FM-qcf & $\begin{array}{l}\text { Progressive start } \\
\text { (on oscillogram) }\end{array}$ & $24-28$ \\
\hline $\begin{array}{l}\text { Pipistrellus } \\
\quad \text { pipistrellus }\end{array}$ & $\begin{array}{l}\text { Soft clicks, } \\
\text { smacking }\end{array}$ & Fast & Irregular & FM-qcf & & $44-49$ \\
\hline $\begin{array}{l}\text { Pipistrellus } \\
\text { pygmaeus }\end{array}$ & $\begin{array}{l}\text { Soft clicks, } \\
\text { smacking }\end{array}$ & Fast & Irregular & FM-qcf & & $52-60$ \\
\hline $\begin{array}{c}\text { Pipistrellus } \\
\text { nathusii }\end{array}$ & $\begin{array}{l}\text { Soft clicks, } \\
\text { smacking }\end{array}$ & Fast & Irregular & FM-qcf & & $38-40$ \\
\hline Pipistrellus sp. & $\begin{array}{l}\text { Soft clicks, } \\
\text { smacking }\end{array}$ & Fast & Irregular & FM-qcf & & $41-43 ; 50-51$ \\
\hline Nyctalus noctula & Metallic clapping & Slow & Regular, alternative & fm-QCF, FM-qcf & & $18-22$ \\
\hline Nyctalus leisleri & Metallic clapping & Slow & Regular, alternative & fm-QCF, FM-qcf & & $24-27$ \\
\hline Plecotus sp. & $\begin{array}{l}\text { Hard clicks, very } \\
\text { quiet }\end{array}$ & Fast & Regular & FM, FM-qcf & D $2-5$, IL $<50$ & $38-55$ \\
\hline
\end{tabular}

$D$ duration (ms), $I L$ interval length (ms), $F M$ frequency modulation, $Q C F$ quasi-constant frequency, $f m-Q C F$ a call with short portion of modulated frequency and predominant part of quasi-constant frequency, $F M-q c f$ a call with predominant part of modulated frequency and a short ending of quasiconstant frequency 
purpose, we compared actual numbers of observations in four classes $(\mathrm{N}, \mathrm{E}, \mathrm{S}$ and $\mathrm{W}$, data from windless nights were excluded) to the expected numbers, to see whether bat observations were distributed in proportion to the number of halfevenings with a particular wind direction. The data from the 2 years were combined for every test.

Generalized additive mixed model (GAMM) was used to investigate the effects of habitat characteristics and parameters of controls on the occurrence of bats. We performed GAMM with binomial error distribution and logit link and used occurrence (presence vs. absence) of bats during control on each section of the study transect as a response variable. In total, data for 427 walks distributed over three to five sections in 18 transects and 2 years were available and used as single records in the modelling. As results from separate controls performed in the same transects and sections are not fully independent as well as data from the same section of a given transect over different walks, we used transect ID and section ID as random factors in GAMM. Moreover, we controlled for the effect of year by including it as random factor in the model. Six explanatory variables were used in modelling: (1) habitat as categorical factor with eight levels, (2) order of control as categorical factor with two levels - evening vs. night, (3) speed of wind and (4) temperature as two covariates. Moreover, two variables, day of year and distance to mainland, were fitted as interaction of the penalized thin plate regression splines with knots number set to 10 to keep the fit relatively simple (the higher the number, the more complicated the fit is). Splines are formed by smoothly joining two or more polynomial curves, and the number of joins is chosen to minimize generalized cross validation criterion resulting in optimal degree of smoothness. As an effect, we were able to test the non-linear relationship between occurrence of bats and distance to mainland changing over the study period. We used "mgcv" package (Wood 2006) in R program (R Core Team 2013).

\section{Results}

Across the two seasons, 129 detector observations of six bat species were recorded on the Hel Peninsula, including serotine, E. serotinus; Nathusius' pipistrelle, $P$. nathusii; common pipistrelle, $P$. pipistrellus; soprano pipistrelle, P. pygmaeus; noctule, N. noctula; and an unidentified Myotis sp. Apart from the latter, some other observations were also classified only to the genus level, due to the low quality of audio recording or a very short time of observation.

During early summer, only 31 detector observations of bats were obtained, among which E. serotinus and $P$. pipistrellus were the most numerous. In late summer and autumn (i.e. autumn migration), more than three times more (98) bat passes were recorded, with $P$. nathusii predominating in the sample (Table 2). The number of observations/transect/visit was significantly larger during the autumn migration than during the nursing period (Mann-Whitney $U$ test, $Z=2.80, p=0.005$ ). Except for numerous detector observations, only 10 bat records, mostly of $P$. nathusii, have ever been obtained from the Hel Peninsula. One grounded individual of the particoloured bat $V$. murinus (the seventh species on Peninsula) was found and photographed in spring 2013. Only two bat species can be considered as occasionally breeding on Hel Peninsula. A nursery roost of $P$. nathusii was found in 1996 in the attic of a house in Kuźnica, but a subsequent visit to the

Table 2 The number of bat observations (passes) from ultrasound detection on linear walking transects in both phenological periods in the Hel Peninsula, Poland, in years 2007-2008

\begin{tabular}{|c|c|c|c|c|}
\hline Species & $\begin{array}{l}\text { Pregnancy, lactation and } \\
\text { weaning of young }\end{array}$ & $\begin{array}{l}\text { Autumn migration and } \\
\text { dispersal of nurseries }\end{array}$ & Total & Percent \\
\hline Myotis sp. & - & 6 & 6 & 4.7 \\
\hline Eptesicus serotinus & 7 & 22 & 29 & 22.5 \\
\hline Eptesicus sp. & 3 & 2 & 5 & 3.9 \\
\hline Pipistrellus pipistrellus & 6 & 21 & 27 & 20.9 \\
\hline Pipistrellus pygmaeus & 4 & 2 & 6 & 4.7 \\
\hline Pipistrellus nathusii & 3 & 34 & 37 & 28.7 \\
\hline Pipistrellus sp. & 1 & 2 & 3 & 2.3 \\
\hline Nyctalus noctula & 4 & 6 & 10 & 7.8 \\
\hline Nyctalus sp. & 1 & - & 1 & 0.8 \\
\hline Unidentified & 2 & 3 & 5 & 3.9 \\
\hline Total & 31 & 98 & 129 & 100.0 \\
\hline Median/transect & 0.0 & 1.0 & & \\
\hline Quartiles (25-75\%) & $0.0-1.0$ & $0.0-2.0$ & & \\
\hline Min.--max. & $0.0-9.0$ & $0.0-27.0$ & & \\
\hline
\end{tabular}


same roost in 1997 failed to locate any bats. A nursery colony of $P$. pygmaeus occupied crevices in the roof of a house in Chalupy (2009); however, no bat emergence or concentration of commuting P. pygmaeus was observed in the evening on transect 13 , adjacent to that roost and neighbouring buildings, neither in 2007 nor 2008. No bats or their droppings were found in bird or bat boxes and no individuals hibernated in the abandoned military objects in 2007-2008. However, a single, active Natterer's bat $M$. nattereri was found in late autumn 2014 in a small air-raid shelter, while 14 adult P. nathusii occupied new bat boxes in 2014 (Table 3).

In early summer, no significant correlation between the number of bat observations and the distance between the transect's centroid and the mainland was found (Spearman's rank correlation, $r=-0.07, p=0.8)$. However, a significant, negative correlation was found in late summer $(r=-0.65, p=0.004)$. On the controlled transects, occurrence of bats was affected by the habitat type. Occurrence of bats was the highest in deciduous and coniferous forests and the lowest in coasts and ports (Fig. 2, Table 4). Temperature positively affected the presence of bats, and increase of temperature by $1^{\circ}$ raised the odds of bat occurrence by $37 \%$. The speed of wind had no effect on the presence of bats but their occurrence was by $44 \%$ less likely during night than in evening part of the sampling (Table 4). The interaction of day of year and distance to mainland fitted with splines was highly significant, indicating that occurrence of bats was increasing over time (from spring to autumn) but this increase depended on the distance from mainland (Table 4, Fig. 3). On the transects located far from mainland (over $20 \mathrm{~km}$ ), the mean probability of occurrence of bats was rather stable over time and was below 0.1. On transects located close to the mainland (10 km and less), the probability of bats' occurrence was low at the beginning of the season (Fig. 3b, c) but, after day 220-240 (ca. mid-August), increased rapidly exceeding 0.8 in late autumn (beginning of October, Fig. 3d). The numbers of bat observations differed

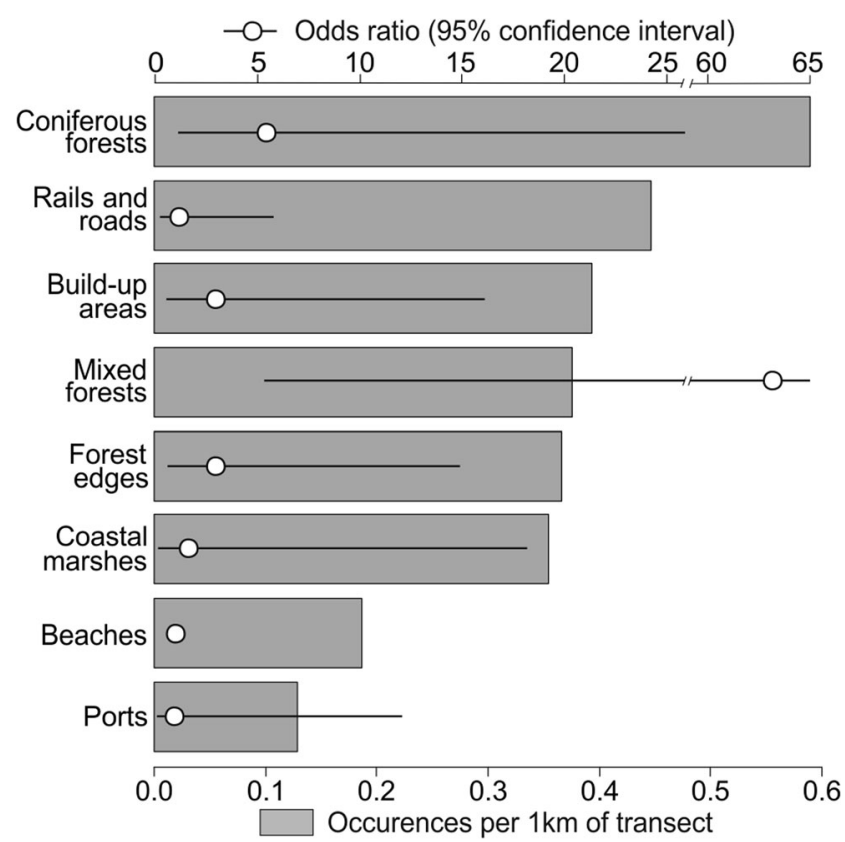

Fig. 2 Habitat preferences of bats on Hel Peninsula, Poland (all species and months lumped together for 2007-2008). The preferences are expressed as model parameter estimates (odds ratio with $95 \%$ confidence intervals) from generalized additive mixed model presented in Table 3. Additionally, mean occurrences per $1 \mathrm{~km}$ of transect are visualized with bars

significantly in relation to wind direction from expected $\left(\chi^{2}=\right.$ $18.84, \mathrm{df}=3, p=0.0003)$; more bats than expected were observed in westerly winds (chi-squared $2 \times 2$ test, $\chi^{2}=4.84, p=$ $0.03)$, whereas fewer than expected bats were observed in southerly winds $\left(\chi^{2}=10.53, p=0.001\right)$.

\section{Discussion}

We confirmed only the second prediction that bat activity on the Hel Peninsula would increase between early summer and

Table 3 Additional qualitative records of bats from the Hel Peninsula

\begin{tabular}{|c|c|c|c|c|c|}
\hline Locality & Date & Species & Method & Number, sex and age & Comments \\
\hline Kuźnica & 23 July 1996 & Pipistrellus nathusii & $\mathrm{rc}$ & incl. juv. & Colony, attic, house \\
\hline Hel & 7 July 2006 & Pipistrellus nathusii & $\mathrm{f}$ & $1 \delta^{\lambda}$ ad. & Near the chimney of a house \\
\hline Kuźnica & 24 April 2007 & Pipistrellus nathusii & $\mathrm{mn}$ & $10^{\pi}$ & Bird ringing station \\
\hline Kuźnica & 25 April 2007 & Pipistrellus nathusii & $\mathrm{mn}$ & $10^{\pi}$ & Bird ringing station \\
\hline Kuźnica & 7 May 2007 & Nyctalus noctula & $\mathrm{mn}$ & 1 & Bird ringing station \\
\hline Kuźnica & 12 May 2007 & Nyctalus noctula & $\mathrm{mn}$ & 1 우 & Bird ringing station \\
\hline Chałupy & 2 June 2009 & Pipistrellus pygmaeus & ec (mn) & 90 (9 + ㅇ ad.) & Colony, roof of the house \\
\hline Hel & 22 May 2013 & Vespertilio murinus & f & 1 & $\begin{array}{l}\text { Grounded near the entrance to the WW2 } \\
\text { concrete shelter recently used for museum exhibitions }\end{array}$ \\
\hline Kuźnica & 22 August 2014 & Pipistrellus nathusii & $\mathrm{rc}$ & 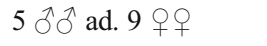 & Bat boxes \\
\hline Chałupy & 21 November 2014 & Myotis nattereri & $\mathrm{rc}$ & 1 (active) & Small air-raid shelter \\
\hline
\end{tabular}

$m n$ mist netting, $f$ found, $p h$ photographed, $e c$ emergence count, $r c$ roost check, $a d$. adult, juv. juveniles 
Table 4 Summary of generalized additive mixed model explaining the occurrence of bats in relation to habitat characteristics and parameters of controls on Hel Peninsula, Poland, in years 2007-2008

\begin{tabular}{|c|c|c|c|c|c|}
\hline Source of variation & $\operatorname{Exp}(B)$ & \multicolumn{2}{|c|}{$95 \%$ CI $\exp (\mathrm{B})$} & $t$ value & $p$ value \\
\hline \multicolumn{6}{|l|}{ Linear fit } \\
\hline Intercept & 0.00 & 0.00 & 0.00 & -7.02 & $<0.0001$ \\
\hline Habitat $=$ coniferous forests & 5.41 & 1.11 & 26.39 & 2.09 & 0.0373 \\
\hline Habitat $=$ mixed forests & 63.38 & 5.30 & 758.71 & 3.28 & 0.0011 \\
\hline Habitat $=$ ports & 0.92 & 0.07 & 12.06 & -0.06 & 0.9493 \\
\hline Habitat $=$ forest edges & 2.92 & 0.57 & 14.88 & 1.29 & 0.1976 \\
\hline Habitat $=$ rails and roads & 1.18 & 0.24 & 5.77 & 0.20 & 0.8399 \\
\hline Habitat=build-up areas & 2.97 & 0.55 & 16.06 & 1.26 & 0.2073 \\
\hline Habitat $=$ coastal marshes & 1.59 & 0.14 & 18.15 & 0.37 & 0.7094 \\
\hline Habitat=beaches (reference) & 1.00 & & & & \\
\hline Order $=$ night & 0.56 & 0.35 & 0.88 & -2.50 & 0.0127 \\
\hline Order $=$ evening $($ reference $)$ & 1.00 & & & & \\
\hline Temperature & 1.37 & 1.14 & 1.65 & 3.36 & 0.0009 \\
\hline Wind speed & 0.88 & 0.72 & 1.08 & -1.25 & 0.2112 \\
\hline Spline fit & edf & & & $F$ value & $p$ value \\
\hline s (day: distance) & 6.36 & & & 9.30 & $<0.0001$ \\
\hline
\end{tabular}

For each level of explanatory variables, odds ratio $(\exp (\mathrm{B}))$ with $95 \%$ confidence interval $(\mathrm{CI})$, test statistics and significance are given and for spline fit, the estimated number of degrees of freedom (edf), test statistics and significance. Statistically significant values are written in bold

late summer/autumn periods but we failed to confirm the first and the third prediction, i.e. that spatial concentrations of foraging individuals would occur in June-July and that no significant relationship would occur between distance from the mainland and bat activity also in the August-September period. Thus, we rejected the hypothesis that the Hel Peninsula hosts permanent breeding bat populations in early summer and serves as a migratory corridor in autumn. Additionally, we found that the presence of bats on the Peninsula was enhanced by westerly winds (i.e. blowing from nearby mainland areas) and that their occurrence was the highest in coniferous and mixed forests, i.e. the habitats providing shelter from stronger winds.

Seven bat species were recorded in the Hel Peninsula during the present study. This number might increase during further studies, as the additional two species were found in the adjacent mainland part of the Polish Baltic Sea Coast, belonging - as the Peninsula itself - to the Coastal Landscape Park. These species are the brown long-eared bat, P. auritus (one hibernating individual in the village of Mosty; Ciechanowski

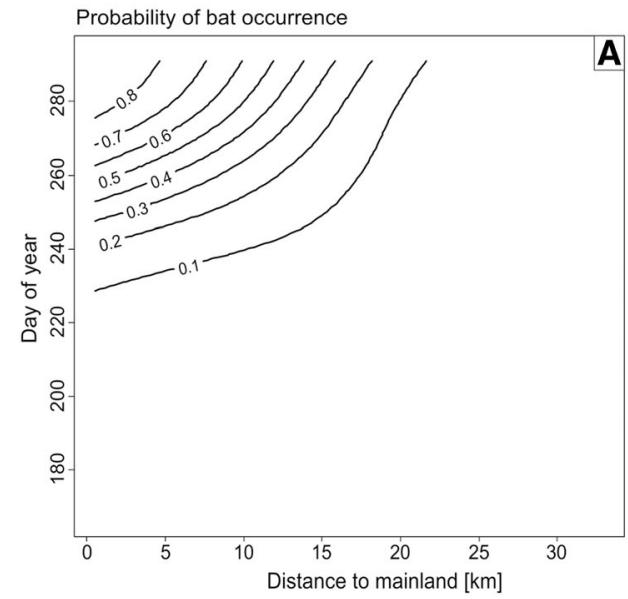

Fig. 3 The effect of distance to mainland on the Hel Peninsula, Poland, relative to the Julian date in 2007-2008, fitted with spline interaction in generalized additive mixed model, on the occurrence of bats, revealed by ultrasound detection. a Averaged probability of bat occurrence marked
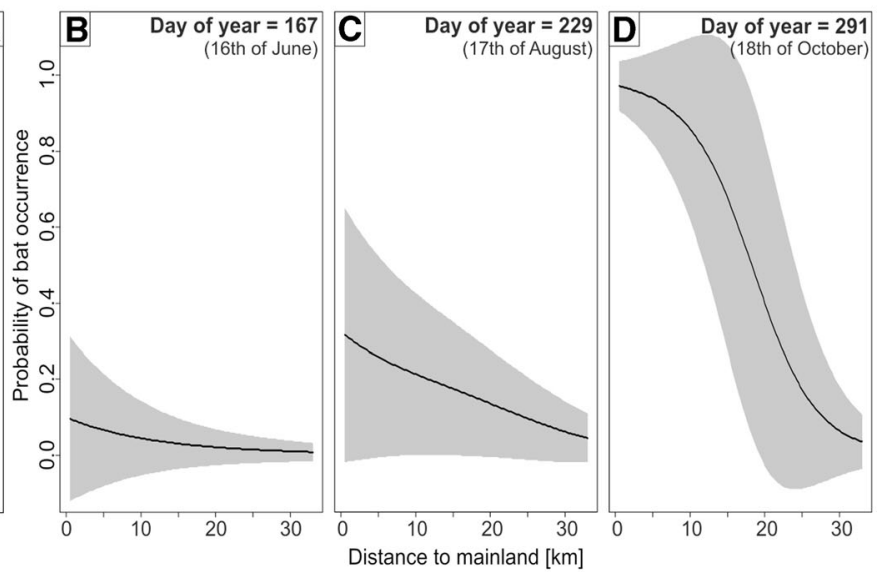

with isolines, b-d expected probability of bat occurrence (black curve with $95 \%$ CI marked in grey) along the distance to mainland for coniferous forest and three different dates corresponding to beginning, middle and end of the study period 
et al. 2000), and the northern bat, E. nilssonii (one, nonbreeding female found grounded in the city of Władysławowo at the base of the Peninsula; Ciechanowski and Szkudlarek 2003). P. auritus, as it emits echolocation calls of very low amplitude (Ahlén 1990), might remain undetected due to the relatively low sensitivity of the frequency division system (Pettersson 2002). Even with more sensitive heterodyne detector, it may be hard to detect Plecotus, as the device is narrowband and contact with such a 'whispering' bat is often too short to adjust frequency. The undetermined Myotis calls most probably represented either Daubenton's bat, $M$. daubentonii, belonging to the most widespread and numerous bat species in northern Poland (Sachanowicz et al. 2006) or Natterer's bat, M. nattereri, recorded in the Hel Peninsula in autumn 2014. The low quality of frequency divided recordings makes it impossible to distinguish between these species of Myotis due to the strong overlap of their call parameters; time-expanded or high-frequency (full spectrum) recordings are necessary to solve this problem.

The Hel Peninsula appears to be an area with poor bat fauna; its climatic and geographic conditions are not conducive to the formation of local bat populations. A relatively low number of bat observations (31 during 36 evenings) and, consequently, almost complete lack of bat activity on the majority of transects in early summer (median 0.0 passes/transect) support this hypothesis. For comparison, in mosaic landscapes of Pomeranian mainland, during 69 evenings in June-July, 4063 bat passes, roughly corresponding to 'bat observations' in the recent study, were recorded; the transects were checked in a similar manner, i.e. two 45-min walks per evening, the first starting $30 \mathrm{~min}$ after sunset (Ciechanowski 2015). Strong gusty winds during the whole year and rapid weather changes can result in unpredictable food resources for bats, which are dominated by airborne insects. Strong winds might be also an obstacle for the movement between roosts. Coastal pine forest, typical for the Hel Peninsula might be poor in natural tree holes, which are the main roost type for some species, due to the low height and diameter of the trees. Moreover, buildings have recently been modernized and adapted to host an increasing number of tourists, an achievement that has, presumably, reduced the number of available daily roosts. The almost complete lack of fresh water bodies might restrict insect prey abundance (rivers, lakes and ponds are the most frequently visited foraging sites; Walsh and Harris 1996, Russ and Montgomery 2002) but especially results in the lack of drinking sites, which are crucial for the maintenance of bat populations (Adams et al. 2003, Adams and Thibault 2006).

We presumed that the observed individuals were mostly solitary males, or non-breeding females, as Johansson and De Jong (1996) suggested for the smallest islands on
Scandinavian lakes. During detector studies, no large concentrations of foraging bat individuals, characteristic for the neighbourhood of maternal roosts and the presence of nursery colonies (Dietz et al. 2006) were found. Probably, a combination of unfavourable conditions in the study area made a formation of nursery colony impossible, at least in 2007-2008, by not maintaining sufficient food resources for pregnant and lactating females. The breeding bat females require abundant and easily available prey due to their high energy requirements (Racey and Speakman 1987); thus, they occupy roosts located as close as possible to optimal foraging sites (Dietz et al. 2006), the availability of which affects the size of the maternal colonies, the number of newborn young, and their growth rate (Kunz 1974; Dietz et al. 2006). Ephemeral nursery colonies were found before (P. nathusii in 1996) and after (P. pygmaeus in 2009) the period of the main detector study. Presumably, in some years, food resources on the Peninsula are more favourable and allow local breeding populations to form de novo. On a transect that appeared later to neighbour a maternal roost of P. pygmaeus in Chałupy, only single bat passes (of any species) were recorded in the early summers of 2007 and 2008, whereas P. pygmaeus was one of the rarest bat species on the Hel Peninsula during the detector study.

Migratory status varies among the bat species recorded on the Peninsula. E. serotinus, predominant in early summer, is considered sedentary (Strelkov 1969). The most numerous species in late summer, i.e. during the autumn migration, was $P$. nathusii, which is known to undertake long-distance migrations; its longest recorded flight was $1905 \mathrm{~km}$ from Latvia to Croatia (Petersons 2004). Such long-distance movements in Europe are also undertaken by $N$. noctula and V. murinus (Strelkov 1969). However, the majority of populations of P. pipistrellus in Central and Western Europe are considered sedentary, although at least part of the eastern populations occasionally migrate (the longest European distance was $1123 \mathrm{~km}$; Hutterer et al. 2005). The majority of these data were, however, collected before P. pygmaeus was distinguished by taxonomists (Jones and Barratt 1999); thus, the proportion of cases that represent long-distance movements of $P$. pipistrellus in Europe might in fact be associated with its sibling species. Judging from scarce available data, P. pygmaeus appeared to be a typical migratory species; the longest known migratory distance covered was $775 \mathrm{~km}$ from Germany to Croatia (Dietz et al. 2009).

In late summer, a threefold increase in the number of bat observations was noted on the Hel Peninsula. Probably, the majority of recorded individuals appeared on the peninsula during the dispersal of nursery colonies located on the mainland after the weaning of young. Young bats leave maternal roosts at the end of July 
(Dietz et al. 2009). Furthermore, adult females leave the colonies after lactation and enrich the bat fauna of the surrounding areas. These phenomena might lead to a significant correlation between the number of bat observations and the distance from mainland, as it might be expected that bat occurrence (and activity) is higher in close proximity to the source of dispersal. That correlation, however, provides evidence that Hel Peninsula is not a migratory corridor for bats in autumn, although the dominant species in that period, $P$. nathusii, is a long-distance migrant (Petersons 2004). Even if most individuals of the latter species visit the Peninsula during their seasonal migration, they probably get there when deviating from typical migratory path along the Baltic Coast and entering a 'dead end' byway. The same path might be used by sedentary E. serotinus during its late summer dispersal, further enriching the local bat fauna.

Some peninsulas can, indeed, act as stopovers and corridors for migrating bats. Orientation of those peninsulas, however, may have to align with the direction of the bats' migratory movements (Dzal et al. 2009; McGuire et al. 2012). Thus, one may expect that the Hel Peninsula is used more intensively as a migratory path by bats in spring, when they migrate along the coast from the west to the east. When birds move from their winter sites to their breeding areas, they enter the Hel Peninsula from its base (Busse 1976). Bats might behave similarly and although detector studies did not cover spring, captures of bats on the seasonal bird ringing station in Kuźnica and the only peninsular record of $V$. murinus support this suggestion. During the autumn migration, most birds, and probably bats, which move from the east to the west, also fly along the coast and thus avoiding the Hel Peninsula, which would lead them back to the east if they entered it. The Vistula Spit, another section of the Polish Baltic Sea Coast with a similar origin and morphology, which separates the Gulf of Gdańsk from the Vistula Lagoon, represents a different situation. It runs from the northeast to the southwest and thus acts as a main migratory corridor for $P$. nathusii, which results in a several-fold increase in their number in August and September (Jarzembowski 2003). However, we cannot exclude that a significant portion of individuals migrate along the coast of the Gulf of Gdańsk in autumn and might be brought to the Hel Peninsula accidentally by stronger winds from the adjacent mainland. A change in flight direction caused by strong winds was suspected to be the reason for the occurrence of $P$. nathusii on oil platforms in the North Sea (Boshamer and Bekker 2008). The slight prevalence of bat observations during westerly winds (i.e. blowing from mainland), compared to those in other wind directions supported this hypothesis. Westerly winds may enhance dispersal of local individuals from mainland; however, in both cases, their association with increase in the number of bat observations suggests that bat fauna of the Hel Peninsula becomes enriched by weather-assisted influx of individuals from outside, more or less distant areas.

Some bats that use the Hel Peninsula during autumn migration might represent individuals flying across the Baltic Sea from Scandinavia. This might be a further explanation for the much more intensive bat activity at the base of the Peninsula, i.e. the closest point to the southern coast of Sweden. Migration of $P$. nathusii across the Baltic Sea to Poland was suggested by Ahlén (1997), who observed individuals moving from projecting points of Scandinavia into the open sea. Some bat species banded in Sweden were recaptured on the other side of the Baltic Sea, including $N$. noctula recorded in Germany and P. nathusii recorded in Germany and Belgium (Ahlén 1997). Later study allowed the collection of 4051 observations of bats belonging to 11 species that crossed the Baltic Sea, including some species classified as sedentary (Ahlén et al. 2009). Additionally, stable isotope analysis of fur of $N$. noctula wintering in Germany revealed that some of them are of Scandinavian origin (Voigt et al. 2014).

Preference to deciduous and mixed woodlands by hunting and commuting insectivorous bats was reported in earlier studies (Russ and Montgomery 2002, Walsh and Harris 1996). However, that habitat class on Hel Peninsula is of marginal importance only. Coniferous woodlands have been reported as avoided by bats (Russ and Montgomery 2002), but this is not the case in landscapes dominated by such forests, e.g. in Finland (Wermundsen and Sivonen 2008) or, as we found, in the Polish Baltic Sea Coast. Also, Walsh and Harris (1996) found that bats selected coniferous forest edges and openings, along with deciduous forests. On islands and peninsulas surrounded by sea, any patch of woodland is, presumably, selected by bats, irrespective of tree species composition, as it provides shelter from strong winds and amount of prey unavailable in the nearby open areas. Observed habitat selection might be treated as evidence contrary to the hypothesis that Hel Peninsula acts as a migratory corridor, as migrating P. nathusii, for example, do not stay for long in any particular type of habitat, as they appear not to use stopovers, but instead apply a fly-and-forage strategy (Šuba et al. 2012). However, some long-distance migrants (e.g. Nearctic Lasionycteris noctivagans) regularly use stopovers (Dzal et al. 2009; McGuire et al. 2012); thus, they might be expected to select the most productive habitats for refuelling.

Our study confirmed that some topographically isolated parts of the sea coasts, such as sandbars and peninsulas, can host only a very impoverished summer bat fauna, both qualitatively and quantitatively; however, bat population density (here deduced from bat activity, treated as proxy) increases during the period of seasonal migrations and post-breeding dispersal, even if they do not act as a part of the migratory corridor. 
Acknowledgments We would like to thank Urszula Anikowska and Tomasz Narczyński who collected part of the acoustic data, Karol Jakusz-Gostomski for help in the fieldwork, Ryszard Kretkiewicz from the Museum of Coastal Defence in Hel for providing photographs of V. murinus, Grażyna Sadowska for providing observation of M. nattereri, and Martyna Jankowska-Jarek and Konrad Bidziński for data about P. nathusii occupying bat boxes.

Open Access This article is distributed under the terms of the Creative Commons Attribution 4.0 International License (http:// creativecommons.org/licenses/by/4.0/), which permits unrestricted use, distribution, and reproduction in any medium, provided you give appropriate credit to the original author(s) and the source, provide a link to the Creative Commons license, and indicate if changes were made.

\section{References}

Adams RA, Thibault KM (2006) Temporal resource partitioning by bats at water holes. J Zool 270:466-472

Adams RA, Pedersen SC, Thibault KM, Jadin J, Petru B (2003) Calcium as a limiting resource to insectivorous bats: can water holes provide a supplemental mineral source? J Zool 260:189-194

Ahlén I (1983) The bat fauna of some isolated islands of Scandinavia. Oikos 41:352-358

Ahlén I (1990) Identification of bats in flight. Swedish Society for Conservation of Nature and The Swedish Youth Association for Environmental Studies and Conservation, Stockholm

Ahlén I (1997) Migratory behaviour of bats at south Swedish coasts. Z Säugetierkd 62:375-380

Ahlén I, Baagøe HJ, Bach L (2009) Behavior of Scandinavian bats during migration and foraging at sea. J Mammal 90:1318-1323

Barataud M (1996) The inaudible world. The world of bats. Acoustic identification of French bats. Sittelle. Editions des voix de la Nature. Mens (+2 CD-ROM)

Baagøe HJ (2001) Danish bats (Mammalia: Chiroptera): atlas and analysis of distribution, occurrence and abundance. Steenstrupia 26:1117

Boshamer JPC, Bekker JP (2008) Nathusius' pipistrelles (Pipistrellus nathusii) and other species of bats on offshore platforms in the Dutch sector of the North Sea. Lutra 51:17-36

Busse P (1976) The spring migration of birds at the east part of Polish Baltic Sea Coast. Operation Baltic paper no. 27. Acta Zool Cracov 21:121-161

Ciechanowski M (2015) Habitat preferences of bats in anthropogenically altered, mosaic landscapes of northern Poland. Eur J Wildl Res 61: 415-428

Ciechanowski M, Przesmycka A, Duriasz J (2000) Bats (Chiroptera) of Nadmorski Landscape Park. In: Latowski K (ed) Biological studies. Bogucki Wydawnictwo Naukowe, Poznań, pp 146-151 (in Polish with English summary)

Ciechanowski M (2003) Bat fauna of Darżlubska Forest. Nietoperze 4: 45-59 (in Polish with English summary)

Ciechanowski M, Szkudlarek R (2003) First records of northern bat Eptesicus nilssonii (Keyserling \& Blasius 1839) in Pomerania region. Nietoperze 4:105-107 (in Polish with English summary)

Constantine DG (2003) Geographic translocation of bats: known and potential problems. Emerg Infect Dis 9:17-21

Cryan PM, Brown AC (2007) Migration of bats past a remote island offers clues towards the problem of bat fatalities at wind turbines. Biol Conserv 139:1-11

Dietz M, Encarnação JA, Kalko EKV (2006) Small scale distribution patterns of female and male Daubenton's bats (Myotis daubentonii) Acta Chiropter 8:403-415
Dietz C, Helversen O, Nill D (2009) Bats of Britain, Europe and Northeastern Africa. A\&C Black, London

Dzal Y, Hooton LA, Clare EL, Fenton MB (2009) Bat activity and genetic diversity at Long Point, Ontario, an important bird stopover site. Acta Chiropter 11:307-315

Fleming T, Eby P (2004) Ecology of bat migration. In: Kunz T, Fenton MB (eds) Bat ecology. The University of Chicago Press, Chicago and London, pp 156-208

Gerstmannowa E (1995) Hel Peninsula — natural base for development. Institute of Environmental Protection, Warszawa (in Polish)

Hatch SK, Connelly EE, Divoll TJ, Stenhouse IJ, Williams KA (2013) Offshore observations of Eastern red bats (Lasiurus borealis) in the Mid-Atlantic United States using multiple survey methods. PLoS One 8(12):e83803. doi:10.1371/journal.pone.0083803

Hedenström A (2009) Optimal migration theories in bats. J Mamm 90: 1298-1309

Hutterer R, Ivanova T, Meyer-Cords C, Rodrigues L (2005) Bat migrations in Europe. A review of banding data and literature. Federal Agency for Nature Conservation, Bonn

Jarzembowski T (2003) Migration of the Nathusius' pipistrelle Pipistrellus nathusii (Vespertilionidae) along the Vistula Split. Acta Theriol 48:301-308

Johansson M, De Jong J (1996) Bat species diversity in a lake archipelago in central Sweden. Biodiversity Conserv 5:1221-1229

Jones G, Barratt E (1999) Vespertilio pipistrellus Schreber, 1774 and Vespertilio pygmaeus Leach, 1825 (currently Pipistrellus pipistrellus and P. pygmaeus: Mammalia, Chiroptera): proposed designation of neotypes. Bull Zool Nomencl 56:182-186

Jones G, Rydell J (1994) Foraging strategy and predation risk as factors influencing emergence time in echolocating bats. Phil Trans R Soc B 346:445-455

Jüdes U (1989) Analysis of the distribution of flying bats along linetransects. In: Hanák V, Horaček I, Gaisler J (eds) European Bat Research 1987. Charles University Press, Praha, pp 311-318

Kondracki J (1998) Regional geography of Poland. Polish Scientific Publishers, Warszawa (in Polish)

Kunz TH (1974) Feeding ecology of a temperate insectivorous bat (Myotis velifer). Ecology 55:693-711

Lüttschwager H (1939) Die Säugetiere des danziger Gebietes und früheren Provinz Westpreussen. II. Die Fledermäuse, Chiroptera. Bericht des Westpreussischen Botanisch-Zoologischen Vereins 61: $42-48$

Machnikowski M (1998) Hel Peninsula - problems of conservation of selected ecosystems under impact of tourism. In: Herbich J, Herbichowa M (eds) Vegetation and flora of Pomerania-diversity, dynamics, conservation. Guide to the field sessions of 51st symposium of Polish Botanical Society 15-19.IX.1998. University of Gdańsk, Gdańsk, pp 125-130, in Polish

McGuire LP, Guglielmo CG, Mackenzie SA, Taylor PD (2012) Migratory stopover in the long-distance migrant silver-haired bat, Lasionycteris noctivagans. J Anim Ecol 81:377-385

Miętus M, Filipiak J, Owczarek M (2005) Threats to Hel Peninsula by weather and climatic phenomena. In: Cyberski J (ed) Condition and threats to the Hel Peninsula. Gdańskie Towarzystwo Naukowe, Gdańsk, pp 59-76 (in Polish)

Petersen A, Jensen J-K, Jenkins P, Bloch D, Ingimarsson F (2014) A review of the occurrence of bats (Chiroptera) on islands in the North East Atlantic and on North Sea installations. Acta Chiropter 16:169-195

Pettersson L (2002) The properties of sound and bat detectors. In: Brigham RM, Kalko EKV, Jones G, Parsons S, Limpens HJGA (eds) Bat echolocation research-tools, techniques and analysis. Bat Conservation International, Austin, Texas, pp 9-12

Petersons G (2004) Seasonal migrations of north-eastern populations of Nathusius' bat Pipistrellus nathusii (Chiroptera). Myotis 41-42:29-56 
Przewoźniak M (1979) Structure of geographical environment on Hel Peninsula. Zeszyty Naukowe Wydziału Biologii i Nauk o Ziemi Uniwersytetu Gdańskiego, Geografia 10:117-141 (in Polish)

Racey PA, Speakman JR (1987) The energy costs of pregnancy and lactation in heterothermic bats. Symp Zool Soc Lond 57:107-125

R Core Team (2013) R: a language and environment for statistical computing. R Foundation for Statistical Computing, Vienna, Austria. URL http://www.R-project.org/

Russ JM, Montgomery WI (2002) Habitat associations of bats in Northern Ireland: implications for conservation. Biol Conserv 108: $49-58$

Rydell J, Bach L, Bach P, Diaz LG, Furmankiewicz J, Hagner-Wahlsten $\mathrm{N}$ et al (2014) Phenology of migratory bat activity across the Baltic Sea and the south-eastern North Sea. Acta Chiropter 161:139-147

Sachanowicz K, Ciechanowski M, Piksa K (2006) Distribution patterns, species richness and status of bats in Poland. Vespertilio 9-10:151-173
Strelkov PP (1969) Migratory and stationary bats (Chiroptera) of the European part of the Union. Acta Zool Cracov 14:369-439

Šuba J, Petersons G, Rydell J (2012) Fly-and-forage strategy in the bat Pipistrellus nathusii during autumn migration. Acta Chiropter 14(2): 379-385

Voigt CC, Lehnert LS, Popa-Lisseanu AG, Ciechanowski M, Estók P, Gloza-Rausch F, Görföl T, Göttsche M, Harrje C, Hötzel M, Teige T, Wohlgemuth R, Kramer-Schadt S (2014) The trans-boundary importance of artificial bat hibernacula in managed European forests. Biodiv Conserv 23:617-631

Walsh AL, Harris S (1996) Foraging habitat preferences of vespertilionid bats in Britain. J Appl Ecol 33:508-518

Wermundsen T, Sivonen Y (2008) Foraging habitats of bats in southern Finland. Acta Theriol 53:229-240

Wood SN (2006) Generalized additive models: an introduction with R. Chapman and Hall/CRC 